\title{
SEISMICITY OF THE GARLOCK FAULT, CALIFORNIA
}

\author{
By Luciana Astiz and Clarence R. Allen
}

\begin{abstract}
The Garlock fault is a 265-km-long left-slip fault striking northeastward from the San Andreas fault in southern California. Relocations of earthquakes that occurred from 1932 to 1981 on and near this major fault were made using the master-event technique. The spatial distribution of seismicity along the fault is different west and east of its midpoint near Rand, where the largest en-echelon offset and a marked change in strike occur. These two segments also display distinct geologic features and different seismic and aseismic behavior. The 150$\mathrm{km}$-long segment west of Rand has shown continuous low seismic activity during the past $50 \mathrm{yr}$, well-documented aseismic creep, and has a relatively complex fault trace. In contrast, the 155-km-long segment east of Rand has very few small earthquakes, no demonstrable creep, and a simpler fault trace. $P$-wave firstmotion studies substantiate predominantly left-slip motion along the Garlock fault. Overall energy release during this 50 -yr period gives a seismic moment rate of $2.75 \times 10^{21}$ dyne-cm/yr, much lower than that inferred from Holocene geologic offsets, thus indicating that the Garlock fault currently represents a temporal seismic gap, and that the potential exists for large earthquakes. If behavior of the Garlock fault is similar to that of the San Andreas, the western segment of the fault can be compared with the central creeping segment of the San Andreas, and the eastern segment with those segments broken by the 1857 and 1906 earthquakes; thus larger events might be expected on the eastern segment than on the western segment, or, if the entire fault breaks during a single event, larger displacements toward the east.
\end{abstract}

\section{INTRODUCTION}

The Garlock fault is a major tectonic feature of southern California, dividing the Mojave Desert block on the south from the Sierra Nevada and Basin and Range provinces to the north and northwest. This left-slip fault is at least $265 \mathrm{~km}$ long and extends northeastward from its junction with the San Andreas fault, near Gorman, toward the Death Valley fault zone (Figures 1 and 2). A late Mesozoic dike swarm separated $64 \mathrm{~km}$ in a left-lateral sense is believed to represent the total horizontal offset of the fault (Smith, 1962). Although there is abundant evidence of slip along the fault during the last 10,000 yr (e.g., Clark, 1973; Christenson et al., 1980; Roquemore et al., 1982), very little seismic activity has occurred during the last $50 \mathrm{yr}$ relative to some other regions in southern California.

The purpose of this paper is to analyze the historic seismicity of the Garlock Fault, since 1932, and to relate this seismicity to the available geologic and geodetic information. Our attempt is to understand the role of this major left-lateral fault in southern California tectonics, as well as to try to establish, with our limited set of data, its seismic potential for large earthquakes.

\section{Previous Work}

The Garlock fault has been recognized as an extensive tectonic feature of southern California since early studies by Hess (1910), who first identified the fault and named it after the once-populated town of Garlock. Lateral displacement on the fault was first proposed by Hulin (1925), who suggested $8 \mathrm{~km}$ of left-lateral displacement of Quaternary and older rock units along it. Later studies by Noble 


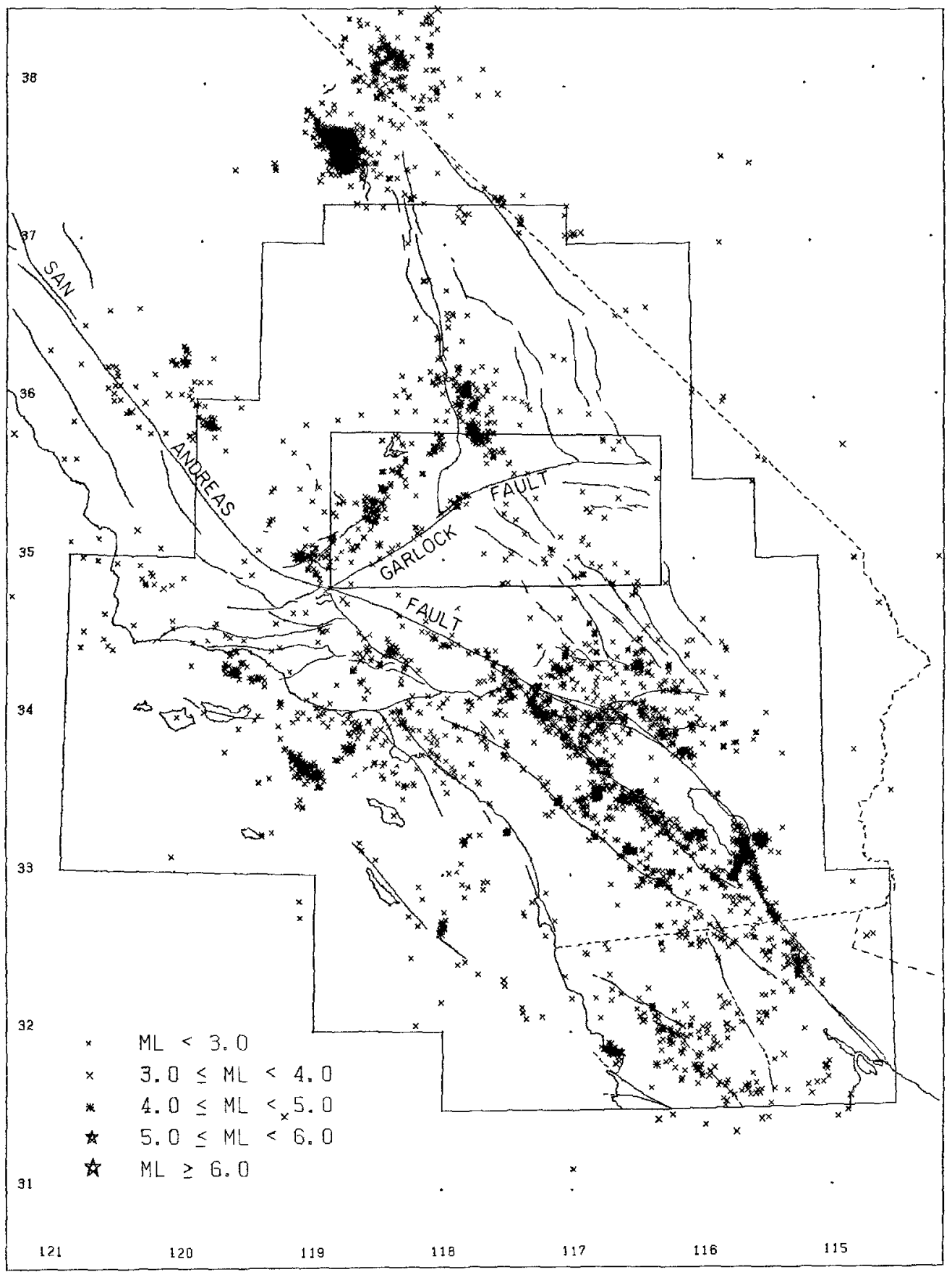

FIG. 1 Southern Calıfornıa seismicity during 1981 from Caltech-USGS catalog. The outer border corresponds to the limits of the southern California array. The inner frame is the limit of Figures 2 and 6 . Notice the cluster of earthquakes along the Garlock fault trace and the smaller activity with respect to many other faults in southern Calıfornia.

(1926), Simpson (1934), Hill and Dibblee (1953), and Hewett (1954a, b, 1955), among others, confirmed the left-lateral nature of the Garlock fault and gave evidence for a significant vertical component of displacement as well. They also suggested that the fault probably originated in early Tertiary time and has been active throughout the late Cenozoic era. However, the total horizontal offset was 
not well established until Smith (1962) correlated a late Mesozoic dike swarm in the Spangler Hills, north of the fault, with a similar swarm in the Granite Mountains, to the south, separated $64 \mathrm{~km}$ in a left-lateral sense. This large horizontal displacement was supported by Michael (1966), from the offset of an early Tertiary (?) fault system that occurs on both sides of the fault. Recent studies by Carter (1982) suggest that strike-slip displacement on the Garlock fault may have begun as recently as about 5.5 my ago.

Hill and Dibblee (1953) regarded the San Andreas, Garlock, and Big Pine faults as major conjugate shears defining a strain pattern of east-west extension and north-south shortening. They suggested also that the "big bend" of the San Andreas was produced as the San Andreas disrupted a once continuous left-lateral Big PineGarlock fault. Davis and Burchfiel (1973) proposed that the Garlock fault is an intracontinental transform structure since it is the boundary of two blocks with differential eastward extension, namely the Basin and Range province to the north of the fault and the Mojave block south of it. Hill (1982) follows both models to explain regional tectonics in California and Nevada.

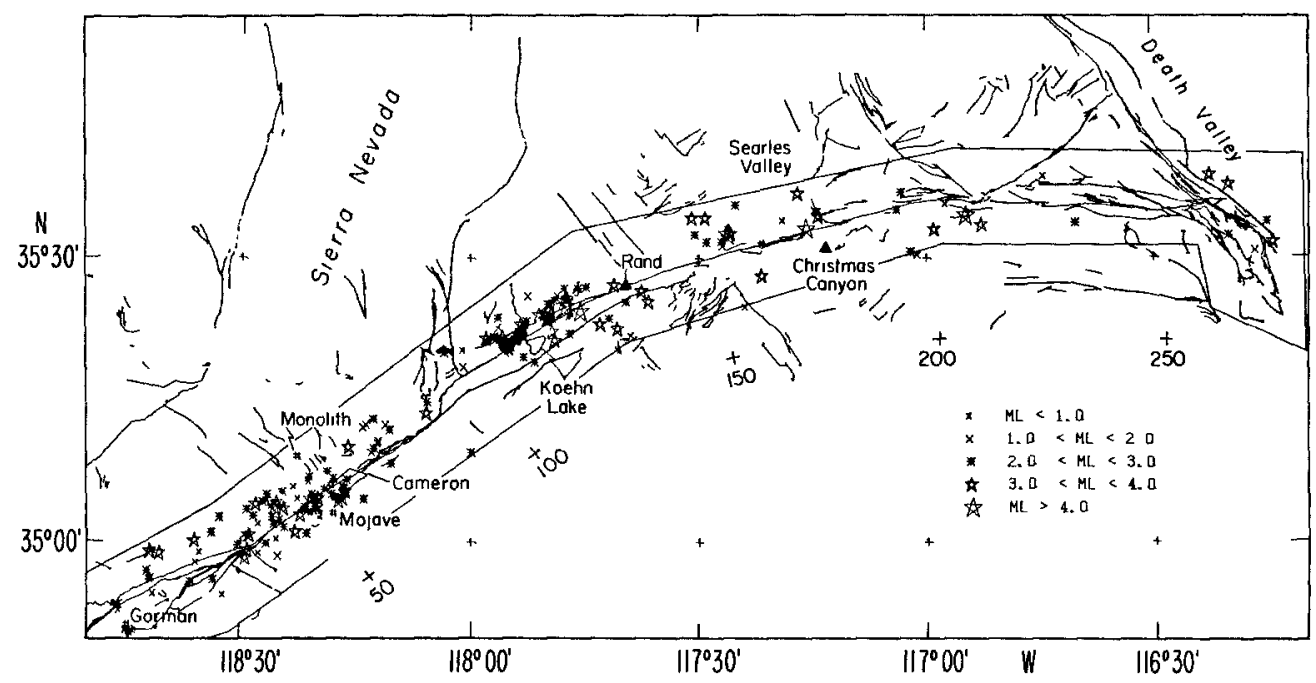

FIG. 2 Earthquake relocatıons from 1932 to $1981 \mathrm{in}$ the Garlock fault zone. The light line corresponds to the $25-\mathrm{km}$-wide zone around the fault from which the earthquakes were taken from the catalog. The numbers in the figure corresponds to kilometers along the fault northeast from Gorman quarry (vertical axes in Figure 3). Solıd circles are quarries, and solid triangles are alignment array locations (from Keller et al., 1978). Faults are taken from Jennings and Strand (1969), Smith (1964), and Jennings et al. (1962).

A marked en-echelon offset in the active fault trace occurs in the vicinity of Koehn Lake and Rand (Figure 2), with the projected trace of the fault entering the valley from the southwest offset 3 to $4 \mathrm{~km}$ from the overlapping trace leaving the valley to the northeast. Indeed, the Koehn Lake depression itself (Cantil Valley) is evidently a pull-apart depression caused by left slip on left-stepping en-echelon fault segments (Clark, 1973; Aydin and Nur, 1982). The negative gravity anomaly associated with Cantil Valley is one of the most spectacular in southern California and reflects a Cenozoic sedimentary fill of more than $3 \mathrm{~km}$ within the elongate, steep-walled basin (Mabey, 1960; Nilson and Chapman, 1974).

The similarity of surface features along the Garlock fault trace with those of historically active segments of the nearby San Andreas fault have led recent studies of the Garlock fault to focus on its Holocene activity. The results of these studies are summarized from west to east along the fault: 
Christenson et al. (1980) report that at Castac Lake, near the intersection of the western end of the fault with the San Andreas, no definitive evidence exists for Holocene displacement, at least on discrete fault surfaces. However, geodetic slip measurements nearby (Snay and Cline, 1980) and the presence of an impressive 300 -m-wide gouge zone along the fault in this area, as seen in the California Aqueduct tunnel excavation, suggest that Holocene movement may be taking place pervasively throughout a wide zone in this structurally complex area (A. B. Arnold, personal communication). At Twin Lakes, in the Tehachapi Mountains $34 \mathrm{~km}$ farther northeast, the fault traverses modern sag-pond deposits, and trenching revealed two episodes of movement (Christenson et al., 1980). The most recent event occurred less than $890 \pm 195{ }^{14} \mathrm{C}$ yr B.P., and the preceding event was more than $2800 \pm 165{ }^{14} \mathrm{C}$ yr B.P. The vertical offsets were 80 to 100 and 55 to $60 \mathrm{~cm}$, respectively, but there was no accurate constraint on horizontal movement. Near Koehn Lake (Figure 2), $65 \mathrm{~km}$ still farther northeast, Carter $(1971,1980)$ determined a slip rate of $8 \mathrm{~mm} / \mathrm{yr}$ for the last $10,000 \mathrm{yr}$ and of $12 \mathrm{~mm} / \mathrm{yr}$ for the Pleistocene epoch by matching displaced alluvial fan gravels. In the same general area, Clark and Lajoie (1974) determined an average horizontal slip rate of $7 \mathrm{~mm} / \mathrm{yr}$ during Holocene time by dating a tufa layer deposited near the crest of an offset gravel bar. Burke (1979), in a trench at the eastern edge of Koehn Lake, recognized 9 to 17 prehistoric earthquakes breaking sediments younger than $14,700{ }^{14} \mathrm{C}$ yr giving a recurrence interval of 865 to 1630 yr. Sieh (1981) suggested an average recurrence interval of 300 to $500 \mathrm{yr}$ as a lower limit. Eastward along the fault, near Christmas Canyon (Figure 2), Smith (1975) suggested that the slip rate is at most $4 \mathrm{~mm} / \mathrm{yr}$ during Holocene time. Roquemore et al. (1982), in a trench at Christmas Canyon, identified six Holocene faulting events that do not displace alluvium less than 500 yr old, giving a recurrence interval of about $1580 \mathrm{yr}$. In summary, the best current estimate of the slip rate along the Garlock fault is about $7 \mathrm{~mm} / \mathrm{yr}$ during Holocene time, and the average recurrence interval of large earthquakes is probably $1,000 \pm$ $500 \mathrm{yr}$.

Geodetic surveys of monuments within a few hundred meters of the Garlock fault have documented contemporaneous left-lateral slip along the westernmost segment of the fault. Measurements of a network at NGS site Ranch, $6 \mathrm{~km}$ north of the Gorman quarry (Figure 2), have shown an average left-lateral slip rate in 10 epochs since 1964 of about $1 \mathrm{~mm} / \mathrm{yr}$, and an extension perpendicular to the fault of about $2.5 \mathrm{~mm} / \mathrm{yr}$ (Snay and Cline, 1980). However, the gouge zone here is at least $300 \mathrm{~m}$ thick southeast of the mapped fault trace (A. B. Arnold, personal communication), and some of the monuments may be within the zone of movement; thus these are minimum figures. The Caltech alignment array at Cameron, $45 \mathrm{~km}$ farther northeast along the fault (Figure 2), has been resurveyed 10 times since its establishment in 1971 and shows clear left-lateral slip rate of about $4 \mathrm{~mm} / \mathrm{yr}$ over a 150 -m-wide zone and perhaps as much as $7 \mathrm{~mm} / \mathrm{yr}$ over a wider zone (Keller et al, 1978; John Louie, personal communication). No slip has been measured in repeated measurements of Caltech alignment arrays still farther northeast along the fault at Rand and Christmas Canyon (Figure 2). Clark (1973) observed fresh en-echelon cracks in 1969 along a short segment of the fault some $20 \mathrm{~km}$ east of Christmas Canyon, but their tectonic origin is questionable. Major tension cracks with vertical displacements of up to $0.6 \mathrm{~m}$ have recently been observed along preexisting fractures within the fault zone south of Koehn Lake (Figure 2), but they are thought to be related to subsidence due to groundwater withdrawal (Clark et al., 1978).

Strain measurements on the Garlock trilateration network across the fault, east 
of Koehn Lake, show strain in the last decade similar to that recorded by many other trilateration networks in southern California. The average principal strain rates measured at the Garlock trilateration network are $\epsilon_{1}=0.02 \pm 0.03$ and $\epsilon_{2}=$ $0.14 \pm 0.03$ ( $\mu$ strain/yr) corresponding to tensional and compressional strain rate vectors oriented $\mathrm{S} 70^{\circ} \mathrm{E}$ and $\mathrm{N} 20^{\circ} \mathrm{E}$, respectively (Savage et al., 1981) or maximum left-lateral shear straining along $\mathrm{N} 65^{\circ} \mathrm{E}$, nearly parallel to the strike of the Garlock fault.

\section{Data ANALYSIS}

During the last $50 \mathrm{yr}$, seismicity on and near the Garlock fault has been very low as compared to that of many other faults in southern California. However, there is a clear alignment of small and moderate events along the fault zone, as compared to adjacent quiescent areas, so that the fault can definitively be classified as "active" in a seismic sense. Figure 1 demonstrates this relationship for 1981, and earlier years were similar. The seismic data used in this study, for the 50 -yr period from 1932 to 1981, are represented by epicenters within a $25-\mathrm{km}$-wide zone centered on the fault (box, Figure 2), and although epicenters outside of this zone are not shown on Figure 2, they are sparse. The events are taken from the Caltech-USGS catalog of southern California earthquakes (Hileman et al., 1973; Friedman et al., 1976; Whitcomb et al., 1978), in addition to more unpublished data.

TABLE 1

\begin{tabular}{cc}
\multicolumn{2}{c}{ VELOCITY MODEL } \\
\hline $\begin{array}{c}\text { P-Wave Velocity } \\
(\mathrm{km} / \mathrm{sec})\end{array}$ & $\begin{array}{c}\text { Upper Depth } \\
(\mathrm{km})\end{array}$ \\
\hline 5.5 & 00 \\
6.3 & 55 \\
67 & 160 \\
7.8 & 37.0 \\
\hline
\end{tabular}

Seismic station coverage and location techniques have changed greatly during this 50-yr period. Following the 1952 Kern County earthquake, for example, several new stations were added to the Caltech seismic network, although the detection level remained at $M \approx 3$ in most of the Garlock fault region. In 1977, many more stations were added, increasing the detection level to $M \approx 1.5$ in this area. Event locations before 1961 were done graphically, with most depths fixed at $16 \mathrm{~km}$ and epicentral locations approximated to the nearest minute, sometimes inducing a tendency for epicenters "to line up". More recently, numerical techniques have been used for location purposes. In an effort to make the location quality more uniform, events used in this study have been relocated using a master-event technique with the computer program QED1 (Johnson, 1979). The velocity model is the same as that presently used in the Caltech locations and is listed in Table 1.

An average of 15 stations, but in no case less than five stations, were used in the relocations. All were at epicentral distances of less than $150 \mathrm{~km}$. The arrival times of $P$ and $S$ waves were taken from the "phase cards" made by the Caltech-USGS staff as part of the routine data processing during these $50 \mathrm{yr}$. Magnitudes of the events were taken directly from the Caltech catalog. Blasts from three nearby quarries-Gorman, Mojave, and Monolith-were taken out of the data set.

To relocate the events, the original $25-\mathrm{km}$-wide strip along the Garlock fault was divided into six regions, each about $45 \mathrm{~km}$ long. Six master events were chosen from 
quality A locations in the Caltech catalog with $M>3.0$ centered in each region (Table 2). The relocation of the events in each of these six regions was then made with respect to the corresponding master event. The master event hypocenter is used as the initial location for the events in the corresponding region. As in the initial locations, most of the events were relocated near the fault trace. A few events prior to 1961 moved out of the area from which they had been chosen, due to a shallower relocation. We feel, however, that relocation of events in a broader area would not have changed dramatically the seismic pattern and the number of events located within the Garlock fault zone as shown in Figure 2. All events were located above $15 \mathrm{~km}$ depth, but most events were located near $7.5 \mathrm{~km}$ depth.

The spatial distribution of seismicity along the Garlock fault is somewhat different to the east and west of Rand, where the largest en-echelon offset is observed and the fault strike changes. Scattered seismicity is observed in the eastern segment of the fault, and a more continuous pattern in the western segment. This difference may be related to its change in strike, since the regional stress field is more favorable to left-lateral slip on the 150 -km-long segment striking approximately $\mathrm{N} 60^{\circ} \mathrm{E}$ than on the eastern $115 \mathrm{~km}$ that strikes almost due east. However, the seismic activity on the western segment of the fault occurs mainly in two segments approximately

TABLE 2

Master Events Locations

\begin{tabular}{|c|c|c|c|c|c|c|c|c|c|c|c|c|c|c|}
\hline Regıon & Year & Month & Day & Hour & Minute & Second & Latitude & (N) & Longitude & (W) & Depth & $M_{L}$ & $N^{*}$ & $\overline{\mathrm{N}}^{\dagger}$ \\
\hline 1 & 197 & 07 & 28 & 11 & 46 & 09.8 & $8 x$ & 58.8 & 118 & 42. & 9 & 3.0 & 34 & 11. \\
\hline 2 & 1980 & 12 & 15 & 22 & 42 & 40.30 & $35^{\circ}$ & $447^{\prime}$ & $118^{\circ}$ & $21.08^{\prime}$ & 6.5 & 3.1 & 23 & 15 \\
\hline 3 & 1970 & 07 & 08 & 09 & 25 & 30.39 & $35^{\circ}$ & $24.92^{\prime}$ & $117^{\circ}$ & $47.74^{\prime}$ & 8.2 & 4.0 & 27 & 17 \\
\hline 4 & 1974 & 06 & 10 & 06 & 44 & 09.99 & $35^{\circ}$ & $32.97^{\prime}$ & $117^{\circ}$ & $26.22^{\prime}$ & 70 & 4.1 & 35 & 19 \\
\hline 5 & 1980 & 03 & 06 & 07 & 45 & 25.48 & $35^{\circ}$ & $34.38^{\prime}$ & $117^{\circ}$ & $14.24^{\prime}$ & 5.2 & 3.4 & 36 & 13 \\
\hline 6 & 1978 & 07 & 17 & 14 & 46 & 1244 & $35^{\circ}$ & $33.62^{\prime}$ & $116^{\circ}$ & $14.16^{\prime}$ & 3.2 & 3.8 & 31 & 12 \\
\hline
\end{tabular}

${ }^{*} N$, number of stations used in the master event.

$+\bar{N}$, average of stations used in the relocations for each region.

$50 \mathrm{~km}$ long, alternating with two still shorter segments with significantly lower activity.

Figure 3 is a time-distance plot along the fault northeast from the Gorman quarry in which the above-mentioned distribution is apparent. Figure $3 a$ includes all events and shows the increase in detection level through time. Figure $3 b$ shows only events of $M_{L} \geqq 3.0$, for which this catalog is thought to be complete in the Garlock fault region. There is no clear time-dependent behavior of seismicity along the fault. No earthquakes were registered on the westernmost $100 \mathrm{~km}$ during 1941 and 1947, nor on the easternmost $100 \mathrm{~km}$ between 1947 and 1973. Seismic quiescence is observed on both ends of the Garlock fault during this 50-yr period, as well as in a $30-\mathrm{km}$ long segment $70 \mathrm{~km}$ from Gorman quarry. Overall, there has been an average of three events per year with $M \geqq 2.5$ on and near the Garlock fault. Peaks of activity were observed in 1953 and 1974, as seen in Figure 5. The largest event in the area during the 50-yr time period occurred in $1974(M=4.3)$.

The seismic moment for the events that have occurred along the Garlock fault zone was estimated from the Thatcher and Hanks (1973) moment-magnitude relation for southern California earthquakes

$$
\log M_{0}=1.5 M_{L}+16.1 \text {. }
$$




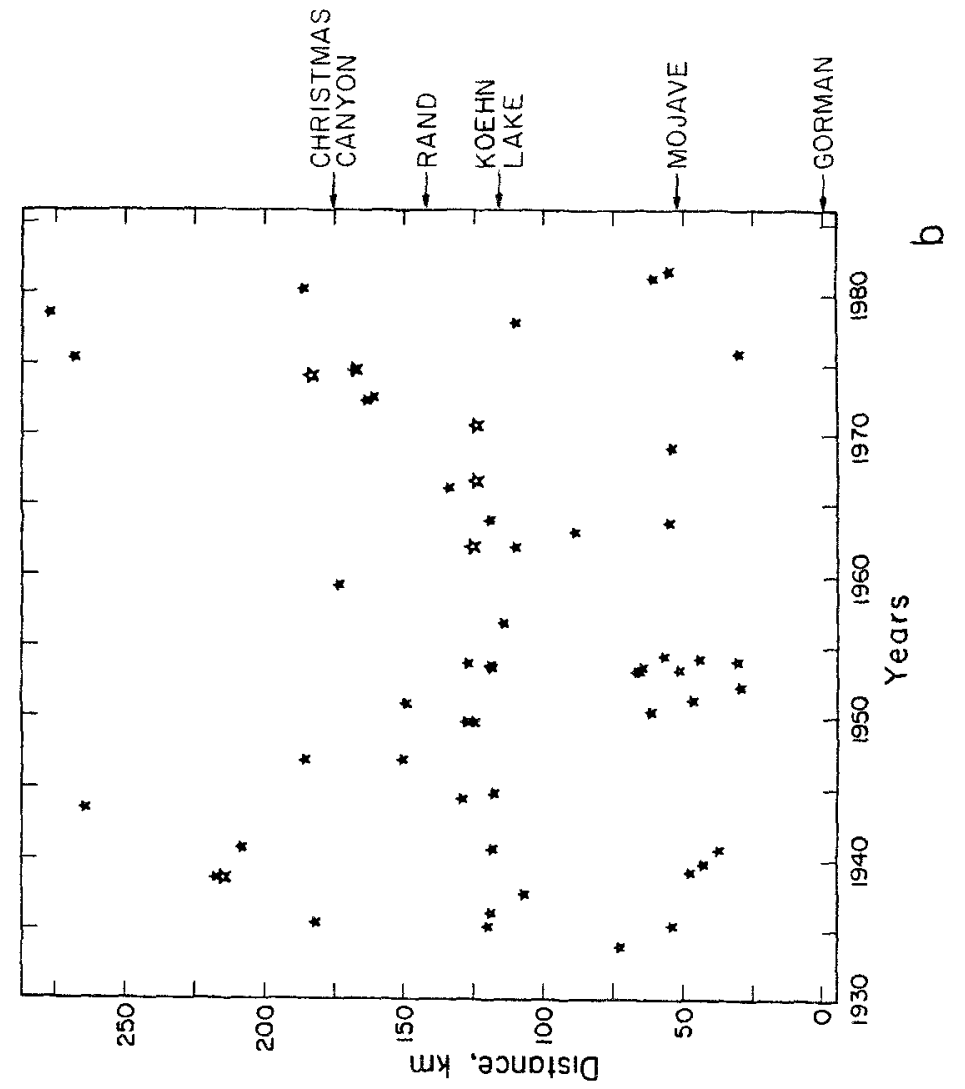

$\sqrt{8} \overline{8}$

ब.

卷

总总

a

워

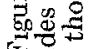

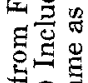

逐咝

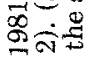

인

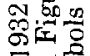

.

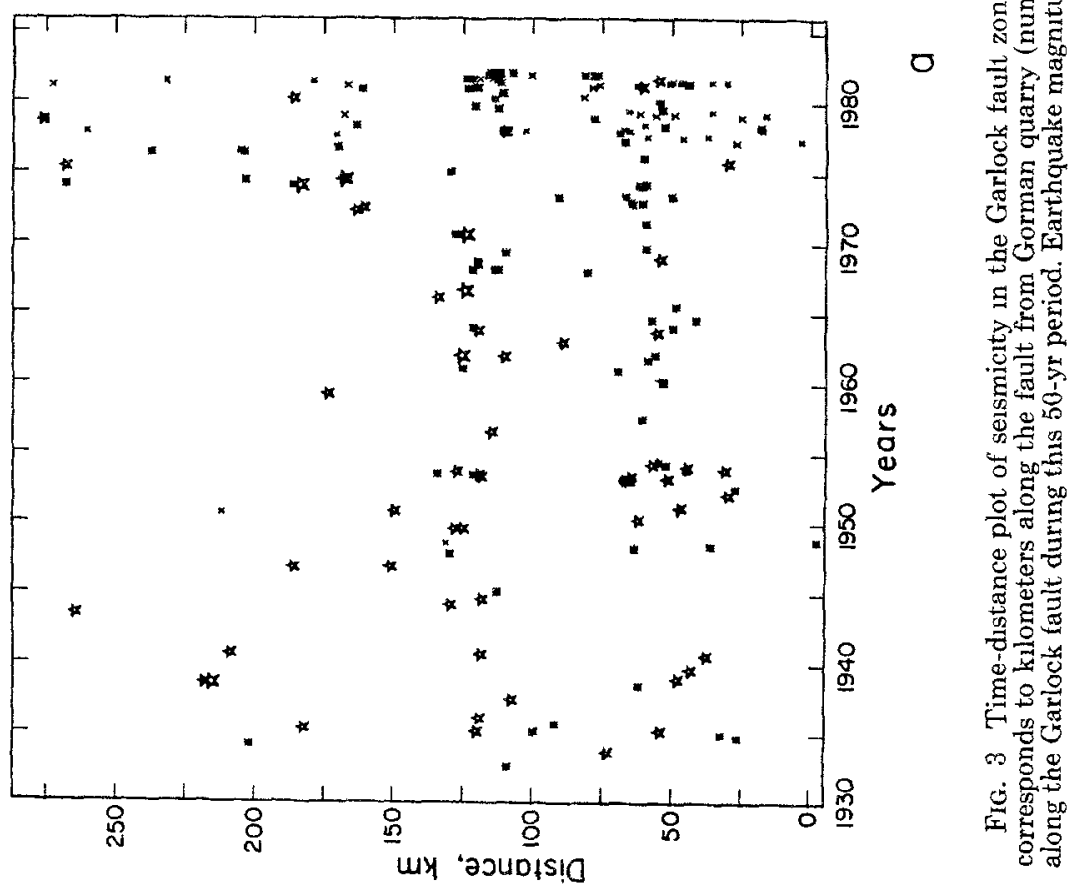


Figure 4 shows the cumulative seismic moment of events of $M_{L} \geqq 2.5$ with distance along the Garlock fault in $25-\mathrm{km}$ intervals. An almost constant seismic moment release of $10^{22}$ dyne-cm is observed during this 50 -yr period. However, toward both ends, the seismic moment release is one or two orders of magnitude smaller, and in the interval from 75 to $100 \mathrm{~km}$, seismic quiescence is apparent, as also seen in Figure 3. The almost constant seismic moment along the fault is unexpected, since the number of events west of Rand with $M_{L} \geqq 3$ is larger than east of it. The fact

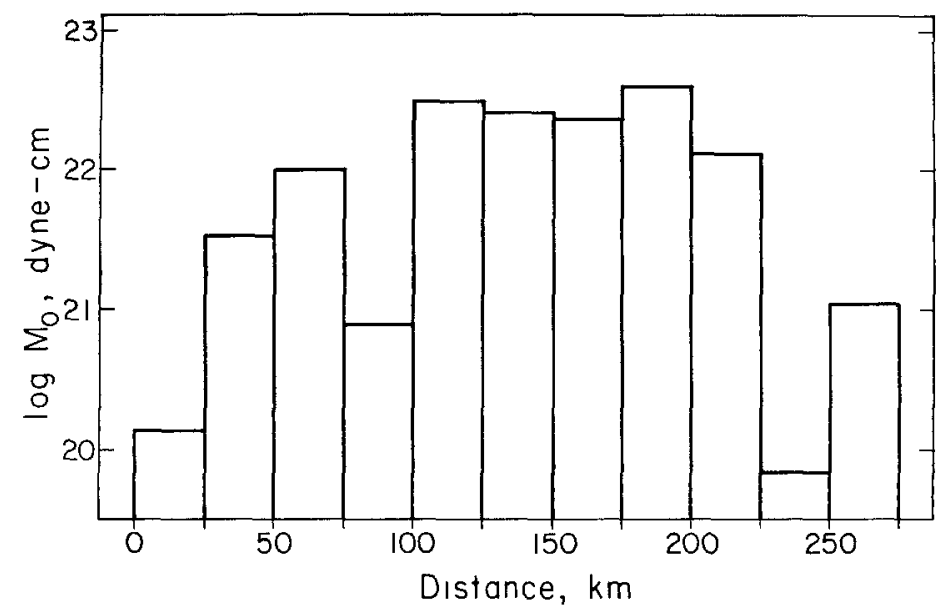

FIG. 4. Bar graph of cumulative seismic moment of events of $M_{L} \geqq 2.5$ from 1932 to 1981 on and near the Garlock fault in $25-\mathrm{km}$ intervals. The horizontal axes corresponds to kilometers along the fault from Gorman quarry (numbers in Figure 2).

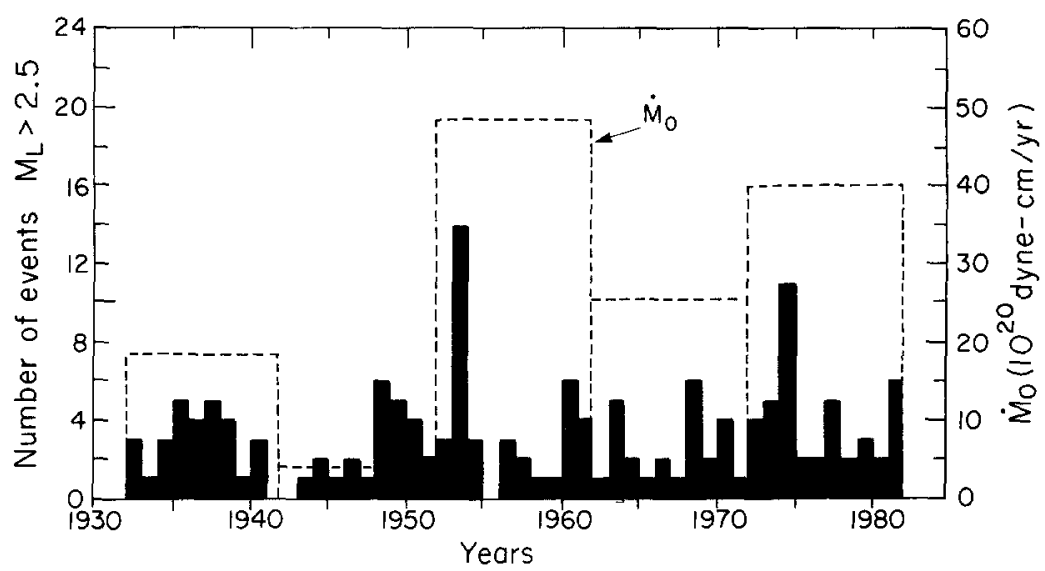

FiG. 5. Bar graph of the number of events of $M_{L} \geqq 2.5$ per year from 1932 to 1981 on and near the Garlock fault The dashed line histogram corresponds to seismic moment rate $M_{0}$ (dyne-cm/yr) averaged over 10-yr periods.

that fewer events in the magnitude range 3 to 4 have occurred along the eastern segment of the Garlock fault is not due to a difference in detection level along it, but to the fact that events of $M_{L} \approx 4$ tend to occur alone, suggesting that the " $b$ value" is different for this eastern segment of the fault. Adding the moments for events of $M \geqq 2.5$ that occurred in the entire area over these $50 \mathrm{yr}$ gives a total moment of $13.75 \times 10^{22}$ dyne-cm and a seismic moment rate of $\dot{M}_{0}=2.75 \times 10^{21}$ dyne-cm/yr. The seismic moment rate for successive $10-y r$ periods was determined in the same way and is shown with the dashed line histogram in Figure 5. From 
1942 to 1952 , the moment release was a factor of 10 lower than the average, while for the other four decades the variation is about a factor of 2 . The seismic moment rate determined from the geologic slip rate is $\dot{M}_{0}=9.2 \times 10^{24} \mathrm{dyne}-\mathrm{cm} / \mathrm{yr}$ (Anderson, 1979).

$P$-wave first-motion studies were made for six earthquakes in the Garlock fault zone from 1978 to 1981, for each of which more than 15 first-motion readings were on file at Caltech (Figure 6). In addition, a composite focal mechanism was determined for six events that occurred in one small area from 1977 to 1981 (Figure 6, no. 5). The computer program FOCPLOT (Whitcomb, 1973) was used to determine the fault-plane solutions shown in Figure 6 and given in Table 3. However, as shown in Figure 7, where detailed focal mechanisms are given, more steeply dipping fault planes (dashed lines) can be solutions for events 2 and 4 . Left-lateral strikeslip motion subparallel to the Garlock fault strike is shown by most of the events

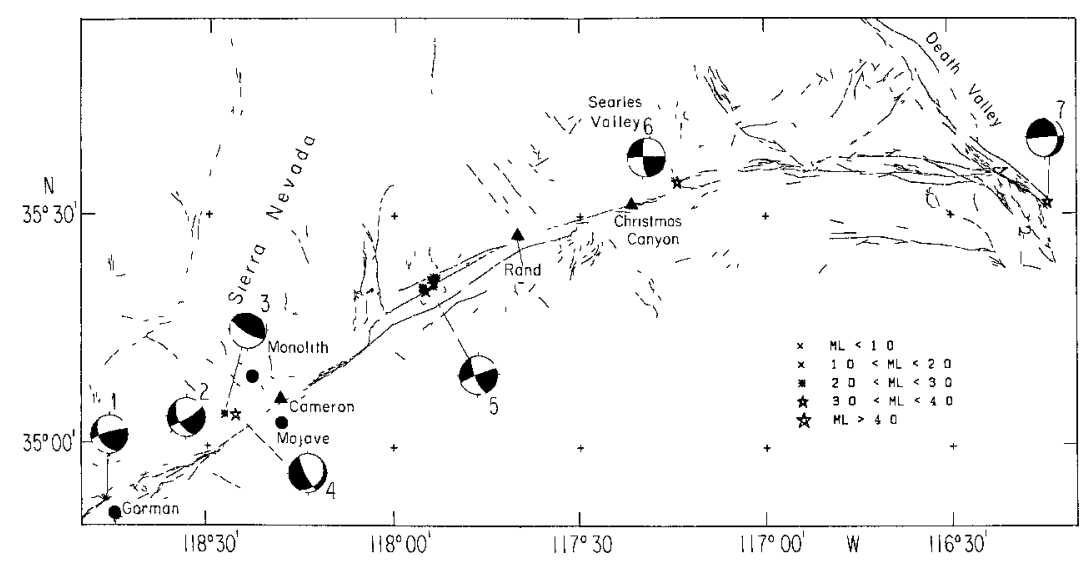

FIG 6 Focal mechanisms for selected events that occurred in the Garlock fault zone between 1977 and 1981 Numbers correspond to those in Table 3 Event 5 is a composite mechanism of six nearby events

[nos. 1, 2, (4), 5, 6, 7]. The thrust-type mechanism determined for event 3 can be explained as the result of applying the regional stress field over favorably oriented fractures near the Garlock fault. The compression and tension axes for most of the events analyzed are oriented N-NE and E-SE, respectively. This is consistent with the strain-rate vector orientation observed by Savage (1981) from the Garlock trilateration network.

\section{Discussion}

This 50-yr seismic record of the Garlock fault zone is short compared to the recurrence interval of perhaps $1,000 \mathrm{yr}$ for large earthquakes determined from geologic offsets (Burke, 1979; Christenson et al., 1980; Sieh, 1981). The spatial seismic pattern along the fault is different west and east of Rand, in that a larger number of events on the western segment contrast with the more scattered pattern to the east, at least throughout the time period of this study (Figures 2 and 3). Clark (1973) describes the Garlock fault trace as progressively better preserved eastward along the fault. He also points out that the fault has a simple trace along much of its length, especially toward the eastern end. However, it becomes a series of many small, discontinuous breaks distributed across a width of 1 to $3 \mathrm{~km}$ near its southwest end, especially where it crosses a $32-\mathrm{km}$-long schist body in the area southwest of 


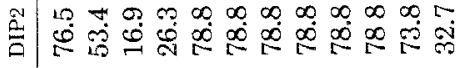

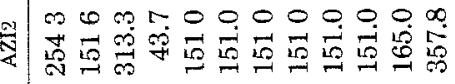

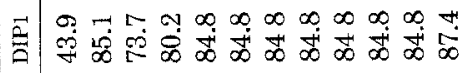

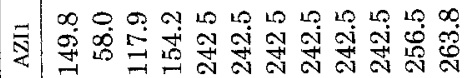

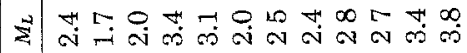

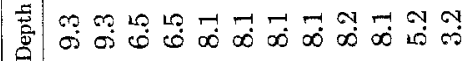

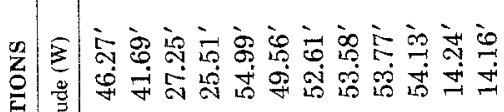

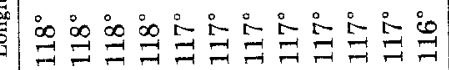

$\infty$

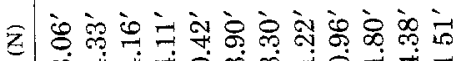

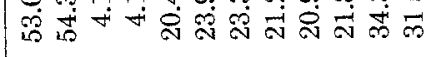

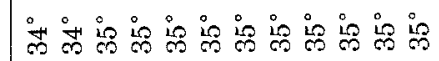

ปั

次

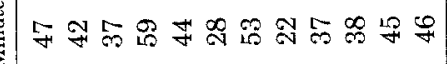

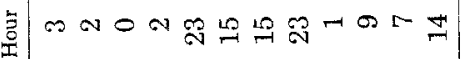

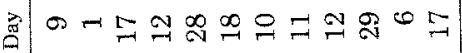

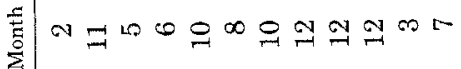

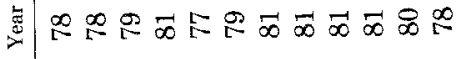

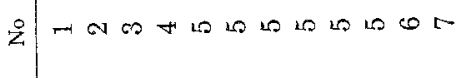


Cameron, and several millimeters/year of left-lateral aseismic slip has been measured in this area. In contrast, the eastern segment of the fault shows no slip during surveys in the last decade (Keller et al., 1978; John Louie, personal communication). Thus, it seems that the Garlock fault, like the San Andreas fault (Allen, 1968), is formed by segments with different seismic and aseismic behavior, as well as distinct associated geologic features.

If the Garlock fault behavior is analogous to that of the San Andreas fault, the western segment of the Garlock fault, $150 \mathrm{~km}$ long, can be compared with the central creeping segment of the San Andreas fault (Allen, 1968). Both have relatively complex fault traces when viewed at a 100 -m scale; creep occurs along both segments and seismic activity at $M \approx 3$ has been regular over the past $50 \mathrm{yr}$, although no truly large earthquakes have occurred, at least in the last $150 \mathrm{yr}$. On the other hand, the eastern segment of the Garlock fault, $115 \mathrm{~km}$ long, more resembles the segments broken by the 1857 and 1906 earthquakes $(M \approx 8)$ on the San Andreas fault, with simple traces as reflected by Quaternary displacement, no creep, and with scattered seismic activity. If this analogy holds, larger earthquakes should be expected on the eastern segment of the Garlock fault than on its western segment, although the possibility of the entire fault breaking during a single event cannot be ruled out.

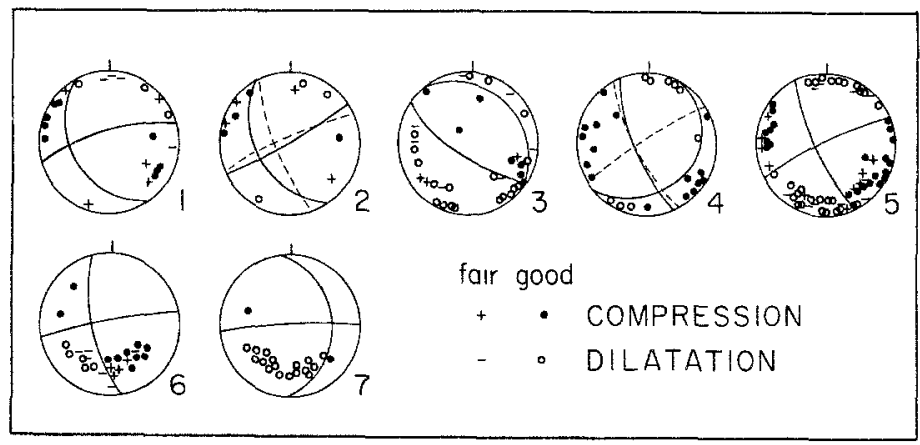

FIG. 7 Detailed $P$-wave first-motion focal spheres for the events listed in Table 3 and shown in Figure 6.

The rate at which seismic moment must be released by earthquakes on a fault to exactly relieve the annual slip across the fault, $\dot{M}_{0}$ is given by (Brune, 1968)

$$
\dot{M}_{0}=\mu A \dot{s}
$$

where $\mu=3 \times 10^{11}$ dyne $/ \mathrm{cm}^{2} . A=$ fault length $\times$ seismic depth $\left(\mathrm{cm}^{2}\right)$ and $s$ is seismic slip rate $(\mathrm{cm} / \mathrm{yr})$.

Let us assume that the slip rate along the whole length of the Garlock fault is 7 $\mathrm{mm} / \mathrm{yr}$ (Clark and Lajoie, 1974) and that the creep rate is $5 \mathrm{~mm} / \mathrm{yr}$ on the western segment of the fault, at least for the last $1,000 \mathrm{yr}$. Then the slip available for elastic strain along the $150-\mathrm{km}$-long western segment of the Garlock fault would be $2 \mathrm{~mm} /$ $\mathrm{yr}$, and for the 115-km-long eastern segment $7 \mathrm{~mm} / \mathrm{yr}$. Using these slip rates and a $15-\mathrm{km}$ seismic depth, one finds $\dot{M}_{0}=1.3 \times 10^{24}$ dyne-cm/yr and $M_{0}=3.6 \times 10^{24}$ dyne-cm/yr for the western and eastern segments, respectively. Since recurrence periods for the Garlock fault are of the order of 1,000 yr (Burke, 1979; Roquemore et al., 1982), from equation (1) the largest magnitude earthquake expected in the western and eastern segments of the fault every $1,000 \mathrm{yr}$ would be of $M=7.3$ and 
$M=7.6$, respectively. Alternatively, the eastern segment may break more often, or a single large event $(M \approx 8)$ might be associated with markedly differential slip along its length.

We know from trenches that there has not been a large earthquake along some segments of the Garlock fault for at least $500 \mathrm{yr}$ (Christenson et al., 1980; Roquemore et al., 1982), and that seismicity in the last $50 \mathrm{yr}$ has been small compared to other faults in California. Furthermore, this seismicity does not account for all the energy release as inferred from geologic offsets. Thus, the Garlock fault should be regarded as currently representing a seismic gap. Special attention should be directed to the eastern segment of the fault due to its higher seismic potential. Unfortunately, most of the Holocene geologic studies along the Garlock fault have been, thus far, concentrated in its western segment, and those in the east lack the constraint of date determinations that are necessary to assess the seismic potential of this major fault in southern California.

\section{Conclusions}

The Garlock fault can be divided into two segments with distinct geologic features and with different seismic and aseismic behaviors. The $150-\mathrm{km}$-long western segment has exhibited continuous low seismic activity during the past $50 \mathrm{yr}$, welldocumented aseismic creep, and has a relatively complex surficial fault trace at a scale of $100 \mathrm{~m}$. In contrast, the eastern $115-\mathrm{km}$-long segment has very few small earthquakes, no demonstrable creep, and a relatively simple surficial fault trace. If the behavior of the Garlock fault is analogous to that of the San Andreas, larger earthquakes might be expected on the eastern segment, or, if the entire fault breaks during a single event, larger displacement toward the east. In any case, comparison of overall seismic energy release during the last $50 \mathrm{yr}$ is $2.75 \times 10^{21}$ dyne-cm/yr, three orders of magnitude smaller than the seismic moment rate estimated with the slip rate obtained from geologic studies, indicating that the fault currently represents a temporal seismic gap, and that the potential exists for large earthquakes.

\section{ACKNOWLEDGMENTS}

We appreciate the help of Carl E. Johnson, Ed Corbett, and Bernard J. Minster, who provided computer programs, and Doug Given, who assisted us in accessing CEDAR data. Kate Hutton kindly provided Figure 1 Discussions with Kerry Sieh, Jeanne Sauber, Art Frankel, Hiroo Kanamorı, Jim Pechmann, and many others of the Caltech Seismological Laboratory were of great benefit. This work was supported by U.S. Geological Survey Contract 14-08-0001-21209 and by the California Division of Mines and Geology Agreement 5-3098.

\section{REFERENCES}

Allen, C. R. (1968) The tectonic environments of seismically active and inactive areas along the San Andreas fault system, Proceedings of Conference on Geologic Problems of San Andreas Fault System, Stanford University Publications, Geol. Scl XI, 70-82.

Anderson, J. G. (1979). Estimating the seismicity from geological structure for seismıc-risk studies, Bull. Selsm. Soc Am 69, 135-158.

Aydin, A. and A. Nur (1982). Evolution of pull-apart basins and their scale independence, Tectonics 1, 91-105.

Brune, J. N (1968). Seismic moment, seismicity and rate of slip along major fault zones, $J$ Geophys. Res 73, 777-784

Burke, D. B. (1979). Log of a trench in the Garlock Fault zone, Fremont Valley, California, US Geol Surv Misc Field Inv Map., MF-1028

Carter, B. (1971). Quaternary displacements on the Garlock Fault, Calıfornıa, Trans Am Geophys Unton 52, 350 .

Carter, B. (1980). Possible Pliocene inception of lateral displacement on the Garlock fault, California, Abstract with Programs, Cordilleran Section, Geol Soc. Am 12, 101. 
Carter, B. (1982). Neogene displacement on the Garlock fault, Calıforma, EOS 63, 1124

Christenson, G. E , J W. La Violette, and J. C. Stepp (1980). Holocene displacement on the western Garlock Fault, Calıfornia, Abstracts with Programs, Cordilleran Section, Geol. Soc Am 12, 402.

Clark, M M (1973). Map showing recently active breaks along the Garlock and associated faults, Californa, U S Geol Surv Misc Geol Inv Map, I-741.

Clark, M. M. and K. R Lajole (1974). Holocene behaviour of the Garlock fault, Abstracts with Programs, Cordilleran Section, Geol Soc. Am 6, 156-157.

Clark, M M., J M. Buchanan-Banks, and T. L. Holzer (1978). Creep along parts of the Garlock fault: possible relation to decline in ground-water levels, Abstracts with Programs, Geol Soc. Am 10, 100.

Davis, G. A. and B. C. Burchfiel (1973) Garlock fault: an intracontinental transform structure, southern California, Geol Soc Am Bull 84, 1407-1422.

Fredman, M. E., J. H. Whitcomb, C. R. Allen, J. A. Hileman (1976). Sessmictty of the Southern California Region, January 1972 to 31 December 1974, Contribution Number 2734, Division of Gelogical and Planetary Sciences, Californı Institute of Technology, Pasadena, Californıa.

Hess, F. L. (1910). Gold mining in the Randsburg quadrangle, California, US Geol Surv Bull 430, 23-47.

Hewett, D. F. (1954a). General geology of the Mojave Desert regıon, Californıa, Calf. Div. Mines Bull. $170,5-20$.

Hewett, D. F. (1954b). A fault map of the Mojave Desert region, Calif Div Mines Bull 170, 15-18.

Hewett, D. F. (1955) Structural features of the Mojave Desert region, Geol Soc Am Spec Paper 62, $377-390$.

Hileman, J. A., C. R. Allen, and J. M. Nordquist (1973). Sessmicity of the Southern Calffornia Regıon January 1932 to 31 December 1972, Contribution Number 2385, Division of Geological and Planetary Sciences, Calıfornia Institute of Technology, Pasadena, California

H.ll, D. P. (1982). Contemporary block tectonics: California and Nevada, J. Geophys Res 87, 54335450.

Hıll, M. L. and T W. Dibblee (1953). San Andreas, Garlock and Bıg Pine faults, Calıfornia, Bull. Geol Soc Am 64, 443-458.

Hulın, C. D. (1925). Geology and ore deposits of the Randsburg quadrangle, California, Calif State Min Bur Bull 95.

Jennıngs, C W., J L. Burnett, and B. W. Troxel (1962) Trona Sheet Map scale 1:250,000, Calıf. Div. of Mines Geol

Jennings, C W., and R. G Strand (1969) Los Angeles Sheet Map scale 1:250,000, Calif. Div. of Mines Geol

Johnson, C E. (1979) I. CEDAR-An approach the computer automation of short-period local seismic networks II Seısmotectonics of the Imperial Valley of southern Calıfornıa, $P h D$ Thesis, Calıfornı Institute of Technology, Pasadena, Calıfornia

Keller, R P., C R. Allen, R. Gilman, N. R. Gouty, and J A Hıleman (1978). Monitorıng slip along major faults in southern Calıfornia, Bull Selsm Soc. Am 68, 1187-1190

Mabey, D. R (1960). Gravity survey of the western Mojave Desert, Calıfornı, US Geol Surv Profess Paper $316-D, 73 \mathrm{pp}$.

Mıchael, E. D (1966). Large lateral displacement on Garlock fault, Calıfornia, as measured from offset fault system, Geol Soc Am Bull 77, 111-114

Nılsen, T H. and R H. Chapman (1974). Bouger gravity map of Californıa, Trona sheet, Calif. Div. of Mines Geol

Noble, L F. (1926). The San Andreas rift and some other actıve faults in the desert region of southeastern Calıfornia, Carnegle Inst Washington, Year Book 25, 415-428.

Roquemore, G R, P E. Smith, and E. W. Banks (1982). Holocene earthquake activity of the eastern Garlock Fault in Christmas Canyon, San Bernardino County, California, Abstracts with Programs, Cordilleran Section, Geol Soc Am 14, 228

Savage, J C., W. H Prescott, M Lisowskı, and N E. King (1981) Strain accumulation in southern Calıfornia, 1973-1980, J Geophys Res 86, 6991-7001.

Sieh, K. (1981).-A review of geological evidence for recurrence times of large earthquakes, Earthquake Prediction-An International Revıew Maurice Ewing Serles, 4, Am. Geophys. Unıon 181-207

Simpson, E. C. (1934) Geology and mineral deposits of the Elizabeth Lake quadrangle, California, Callf. $J$ Mines Geol 30, 371-415.

Smith, A P (1964) Bakersfield Sheet Map scale 1:250,000, Calif Div. Mines Geol

Smith, G I. (1962). Large lateral displacement on Garlock fault, Calıfornıa,as measured from offset dıke swarm, Bull Am Assoc Petrol Geol 46, 85-104

Smith, G I (1975). Holocene movement on the Garlock fault, US Geol Surv Profess. Paper 975, 202 
Snay, R. A. and M. W. Cline (1980). Crustal movement investigations at Tejon Ranch, Californıa, NOAA Technical Rept. 87, $32 \mathrm{pp.}$

Thatcher, W. and T. C. Hanks (1973). Source parameters of southern Californıa earthquakes, J. Geophys Res. 78, 8547-8576

Whitcomb, J. H. (1973). The 1971 San Fernando Earthquake series focal mechanisms and tectonics, $P h D$ Thesus (Part II), California Institute of Technology, Pasadena, California.

Whitcomb, J. H., C. R. Allen, A. C. Blanchard, S. A. Fisher, G. S. Fuis, L. K. Hutton, D. J. Jenkıns, C. E. Johnson, B A. Reed, and K J. Richter (1978). Southern California Array for Research on Local Earthquakes and Teleseısms (SCARLET) Caltech-USGS Monthly Preliminary Epıcenters for January, 1977 to March, 1976, Seismological Laboratory, Division of Geological and Planetary Sciences, Caltech, Pasadena, California.

SEISMOLOGICAL LABORATORY

California Institute of Technology

Pasadena, California 91125

Contribution No. 3908

Manuscript received 23 May 1983 